\title{
Human Monoclonal Antibodies Neutralizing Cytomegalovirus (CMV) for Prophylaxis of CMV Disease: Report of a Phase I Trial in Bone Marrow Transplant Recipients
}

\author{
W. E. Aulitzky, T. F. Schulz, H. Tilg, D. Niederwieser, \\ K. Larcher, L. Östberg, M. Scriba, J. Martindale, \\ A. C. Stern, P. Grass, M. Mach, M. P. Dierich, \\ and $\mathrm{C}$. Huber
}

\begin{abstract}
Division of Clinical Immunobiology (Department of Internal Medicine), University Hospital Innsbruck, and Institute of Hygiene, University of Innsbruck, Austria; Sandoz Forschungsinstitut, Vienna, Austria; Sandoz Research Institute, East Hannover, New Jersey; Institute of Clinical and Molecular Virology, University of Erlangen, Germany; Clinical Research, Sandoz Pharma, Basel, Switzerland
\end{abstract}

\begin{abstract}
The safety and pharmacokinetics of the two neutralizing human IgG1 monoclonal antibodies to cytomegalovirus (CMV) SDZ 89-104 and 89-109 in bone marrow transplant (BMT) recipients was assessed in an open phase $I$ trial. Thirteen patients, 8 seropositive and 5 seronegative for CMV, were treated with allogeneic or autologous bone marrow transplantation. SDZ 89-104 was given to 5 and SDZ 89-109 to 8 patients. Patients were divided into high- and low-dose groups. A fixed prestudy dose of $0.1 \mathrm{mg} / \mathrm{kg}$ was given 4 days before BMT. On days $3,17,31,45,59$, and 73 , patients were treated with either 0.5 or $2 \mathrm{mg} / \mathrm{kg}$ of the respective antibody. Results indicate that doses of $2 \mathrm{mg} / \mathrm{kg}$ of SDZ 89-104 or SDZ 89-109 in alternating weeks can be safely administered to BMT patients. Serum trough levels measured by antiidiotype ELISA were $\sim 10 \mu \mathrm{g} / \mathrm{ml}$ after administration of $0.5 \mathrm{mg} / \mathrm{kg}$ and $\sim 50 \mu \mathrm{g} / \mathrm{ml}$ after treatment with $2 \mathrm{mg} / \mathrm{kg}$ of SDZ 89-104 or SDZ 89-109. High serum levels defined by antiidiotype ELISA techniques closely paralleled increased neutralizing activity. Serum half-lives calculated from these data were $\sim 6$ days.
\end{abstract}

Human cytomegalovirus (CMV) causes most interstitial pneumonias in bone marrow transplant (BMT) recipients, the most frequent and serious infectious complication after allogeneic BMT. Despite all therapeutic efforts, mortality consistently reaches $50 \%$ [1]. Thus, clinical interest has focused on the prevention of CMV infection. Trials using human hyperimmune globulin for prophylaxis of CMV disease have had contradictory results [2]. Although the reasons for these discrepancies are unclear, varying content of neutralizing antibodies in different immunoglobulin preparations may be responsible [3].

Monoclonal antibodies, in contrast, are highly standardizable reagents with defined functional and pharmacokinetic properties. The clinical application of murine monoclonal antibodies, however, is limited by several obstacles. Frequent administration is required because of their short half-lives and the rapid development of human anti-mouse antibodies can

Received 20 October 1990; revised 28 January 1991.

Presented in part: annual meeting of the European Cooperative Group for Bone Marrow Transplantation, 1988 (abstract 272).

The study followed the Declaration of Helsinki; the protocol was approved by the Ethics Committee of University Hospital Innsbruck. Informed consent was obtained from all patients or their parents before therapy.

Grant support: Austrian Research Fund "Zur Foerderung der wissenshaftlichen Forschung" (project 7475).

Reprints or correspondence (present address): Dr. W. E. Aulitzky, Department of Internal Medicine, Division of Hematology, University Hospital Mainz, Langenbeckstr. 1, D-6500 Mainz, FRG.

The Journal of Infections Diseases 1991;163:1344-1347 (c) 1991 by The University of Chicago. All rights reserved. 0022-1899/91/6306-0026\$01.00 effectively neutralize the clinical effects of therapy $[4,5]$. Moreover, most murine monoclonal antibodies lack important immune effector functions [6]. Human monoclonal antibodies may be less immunogenic, should have longer circulation halflives, and thus may be superior for prolonged treatment of patients. We report here the results of the first clinical phase I trial with human monoclonal antibodies in BMT patients.

\section{Patients, Materials, and Methods}

Human monoclonal antibodies neutralizing CMV designated SDZ 89-109 (formerly EV 2-7) and SDZ 89-104 (formerly EV 1-15) were established at the Sandoz Research Institute. Both antibodies are of IgG1 isotype but carry different idiotypes. They were shown to neutralize 50-100 times the $\mathrm{ID}_{50}$ of laboratory CMV strains Towne, Davis, and AD169 and four clinical isolates in the absence of complement in concentrations as little as $1 \mu \mathrm{g} / \mathrm{ml}$ (Scriba M, personal communication). SDZ 89-109 neutralizes by binding to an 82-kDa protein, whereas SDZ 89-104 binds to a disulfide-bonded complex consisting of 58-, 107-, and 163-kDa proteins [7]. The target antigen of SDZ 89-104 has been further characterized using cloned fragments of gp58 of human CMV. These experiments demonstrated that the binding structure for SDZ 89-109 is the same epitope on gp58 (gpB) of CMV that has been described by Utz et al. [8] (Mach $\mathrm{M}$, personal communication).

Four female and nine male patients, 12-52 years old (median, 28), were studied. Eight were seropositive for CMV-specific antibodies before allogeneic ( 8 patients) and autologous BMT ( 5 patients). Patients were treated with either SDZ 89-104 or 89-109. Four days before BMT, all patients received $0.1 \mathrm{mg} / \mathrm{kg}$. On days $3,17,31,45$, 59 , and 73 after BMT, the patients received either 0.5 or $2 \mathrm{mg} / \mathrm{kg}$ of drug by intravenous infusion for $30 \mathrm{~min}$ (table 1). Blood samples 
Table 1. Serum levels and half-lives of human monoclonal antibodies SDZ 89-104 and 89-109 in bone marrow transplant (BMT) patients.

\begin{tabular}{|c|c|c|c|c|c|c|c|c|}
\hline \multirow{4}{*}{$\begin{array}{l}\text { Monoclonal } \\
\text { antibody, } \\
\text { patient }\end{array}$} & \multirow{4}{*}{$\begin{array}{c}\text { Dose } \\
(\mathrm{mg} / \mathrm{kg})\end{array}$} & \multicolumn{4}{|c|}{ Idiotype level $(\mu \mathrm{g} / \mathrm{ml})$} & \multirow{2}{*}{\multicolumn{2}{|c|}{ Neutralization }} & \multirow{4}{*}{$\begin{array}{c}\text { Half-life } \\
\text { (days) }\end{array}$} \\
\hline & & \multirow{2}{*}{\multicolumn{3}{|c|}{ Before administration }} & \multirow{3}{*}{$\begin{array}{c}\text { Peak level } \\
\text { after last } \\
\text { dose }\end{array}$} & & & \\
\hline & & & & & & \multirow{2}{*}{$\begin{array}{l}\text { Before } \\
\text { first dose }\end{array}$} & \multirow{2}{*}{$\begin{array}{c}\text { After } \\
\text { last dose }\end{array}$} & \\
\hline & & 1 & 2 & Last & & & & \\
\hline \multicolumn{9}{|l|}{ SDZ 89-104 } \\
\hline 1 & 0.5 & 0 & 4.8 & 13.6 & 22.3 & $1: 320$ & $1: 320$ & 6.1 \\
\hline 2 & 0.5 & 0 & 3.6 & 4.2 & 18.2 & 0 & $1: 160$ & 4.2 \\
\hline 3 & 0.5 & 0 & 2.8 & 11.0 & 29.6 & $1: 40$ & $1: 160$ & 7.6 \\
\hline 4 & 2 & 0 & 14.8 & 65.9 & 192.1 & 0 & $1: 40$ & 3.2 \\
\hline 5 & 2 & 0 & 13.1 & 60.8 & 53.3 & 0 & 0 & ND \\
\hline \multicolumn{9}{|l|}{ SDZ 89-109 } \\
\hline 1 & 0.5 & 0.1 & 1.6 & 9.3 & 21.7 & 0 & 0 & 8.4 \\
\hline 2 & 0.5 & 0 & 3.4 & 13.8 & 27.3 & $1: 20$ & $1: 20$ & 7.0 \\
\hline 3 & 0.5 & 0.01 & 3.4 & 9.8 & 27.8 & 0 & $1: 40$ & 7.0 \\
\hline 4 & 2 & 0 & 26.9 & 81.3 & 260.9 & 0 & $1: 160$ & 3.2 \\
\hline 5 & 2 & 0.3 & $0.2^{*}$ & 53.2 & 99.8 & $1: 10$ & $1: 80$ & 3.7 \\
\hline 6 & 2 & 0 & 6.7 & 29.0 & 86.1 & $1: 40$ & $1: 80$ & 8.3 \\
\hline 7 & 2 & 0 & 3.5 & $\dagger$ & 23.6 & 0 & $1: 80$ & ND \\
\hline 8 & 2 & 0 & 10.6 & 58.8 & 154.7 & $1: 20$ & $1: 40$ & 14.8 \\
\hline
\end{tabular}

NOTE. ND $=$ not done.

* Received only $0.1 \mathrm{mg} / \mathrm{kg}$ on day 3 after BMT.

$\dagger$ Received monoclonal antibody 3 days before BMT and on days 4 and 17 after transplantation only.

were taken at $0,1,2,12,24,48,72,96,120,144$, and $264 \mathrm{~h}$ after each administration. Vital signs were monitored hourly for the first $4 \mathrm{~h}$ after each infusion of the antibody. Blood counts, liver and kidney function tests, and measurement of serum levels of circulating immune complexes and complement components were done twice weekly.

Polyclonal antiidiotypic antibodies to SDZ 89-109 and 89-104 were prepared by immunizing goats with intact IgG. Sera were affinity purified on SDZ 89-109 or 89-104 coupled to cyanogen bromide-activated sepharose (Pharmacia, Uppsala, Sweden). Antiidiotypic antibodies were coupled to biotin following published standard methods. Wells of ELISA plates (Nunc, Roskilde, Denmark) were coated with $0.2 \mu \mathrm{g}$ of affinity-purified antiidiotypic antibodies to SDZ 89-109 or $89-104(2 \mu \mathrm{g} / \mathrm{rnl})$. Plates were washed and free-binding sites were saturated with 5\% fetal calf serum in PBS and washed again three times. Patient sera $(100 \mu \mathrm{l})$ were added in twofold dilution steps ranging from 1:20 to 1:2560. After incubation for $1 \mathrm{~h}$ at room temperature, the plates were washed five times and incubated with $100 \mu \mathrm{l} /$ well biotinylated antiidiotypic antibodies for another hour. Every plate contained a series of standards. After three more washings, the plates were developed with peroxidase-conjugated avidin (Vector Laboratories, Burlingame, CA) and phenylendiamine (Fluka, Buchs, Switzerland) as a substrate. Extinction was read at $492 \mathrm{~nm}$ in a standard ELISA reader. The serum concentrations of monoclonal antibodies were calculated by linear regression analysis of the logit transformed optical density values, the standard curve serving as a reference. The lower limit of detection of these assays was $\sim 0.01 \mu \mathrm{g} / \mathrm{ml}$.

A linear one-compartment model was found to be appropriate to characterize the pharmacokinetics of both compounds. Even if theoretically the total elimination could be split into an early redistribution phase and a terminal degradation phase, the raw data did not support such behavior. In mathematical terms these concentration/time profiles are $C_{n}(t)=A\left[\left(1-e^{-n k r}\right) /\left(1-e^{-k r}\right)\right] e^{-k \tau}$, which describes the time course of drug concentration $(C)$ of a onecompartment model after repeated dosing. $t$ is the time elapsed since the $n$th dose was administered, $\tau$ is the length of the dosage interval (i.e., 14 days), $A$ is a scaling factor that includes the volume of distribution and the dose administered, and $k$ is the elimination rate constant. In comparison with the very long elimination half-life given by $t_{1 / 2 k}=1 n(2) / k$, the input was assumed to be a bolus injection instead of an infusion. For practical reasons the concentration data of each dosing interval were divided by the respective factor $(1-$ $\left.e^{-n k r} / 1-e^{-k r}\right)$ that transformed the individual multiple dosing profiles to single-dose profiles. For log-linear regression analysis of the resulting profiles, all concentrations of a single patient were merged, simulating a repeated single-dose measurement design.

CMV cultures on human foreskin fibroblasts were done weekly from urine, blood, and saliva by standard methods [9]. CMV-specific antibodies were measured by commercially available ELISAs (Medac, Hamburg, FRG). Positive cultures from urine or blood or seroconversion or a fourfold increase in ELISA titers was considered laboratory evidence of CMV infection. Presence of SDZ 89-109 and 89-104 in the serum did not interfere with the serologic tests as sera of seronegative patients remained negative despite high levels of SDZ 89-109 and 89-104. Before treatment, $12 \mathrm{~h}$ after the second, and immediately before and $12 \mathrm{~h}$ after the last dose of the antibodies, serum samples were tested for neutralizing activity against CMV by a microneutralization test [10].

\section{Results}

We first tested to see if the idiotypes were detectable in randomly selected sera. One serum sample of 30 contained low levels $(0.05) \mu \mathrm{g} / \mathrm{ml}$ ) of the SDZ 89-104 idiotype. In contrast, 15 of 20 sera showed some reactivity in the idiotype 
ELISA for SDZ 89-109 (range, 0.04-0.24 $\mu \mathrm{g} / \mathrm{ml}$ ). None of the five CMV-positive patients who received SDZ-104 had detectable idiotype in their serum before start of treatment. One of the three seropositive patients treated with SDZ 89$109 \mathrm{had} 0.3 \mu \mathrm{g} / \mathrm{ml}$ of the respective idiotype in his pretreatment serum. In addition, the sera of two seronegative patients also had low idiotypic concentrations $(0.01$ and $0.10 \mu \mathrm{g} / \mathrm{ml})$. As these levels were far below those observed after administration of the two antibodies, endogenous levels seem not to interfere with the detection of therapeutically administered antibody.

Administration of the antibodies resulted in a rapid increase of the respective idiotype (figure 1). Peak serum and trough levels are shown in table 1. The half-life of either compound was 3-14 days (average, 6; table 1). Neutralizing activity in the serum increased after treatment in all patients receiving the higher doses of SDZ 89-109, whereas lower doses led to only a marginal increase of CMV neutralizing serum activities. A significant correlation was observed between concentrations of antibody measured by the antiidiotype ELISA and the neutralizing activity $(r=.7, P<.001)$ in patients treated with SDZ 89-109. Only minor increments were seen in the patients treated with $2 \mathrm{mg} / \mathrm{kg} \mathrm{SDZ} \mathrm{89-104}$. The increase observed after treatment with the lower dose of this antibody cannot be attributed solely to therapy as all three patients had laboratory evidence of $\mathrm{CMV}$ infection during the study period.

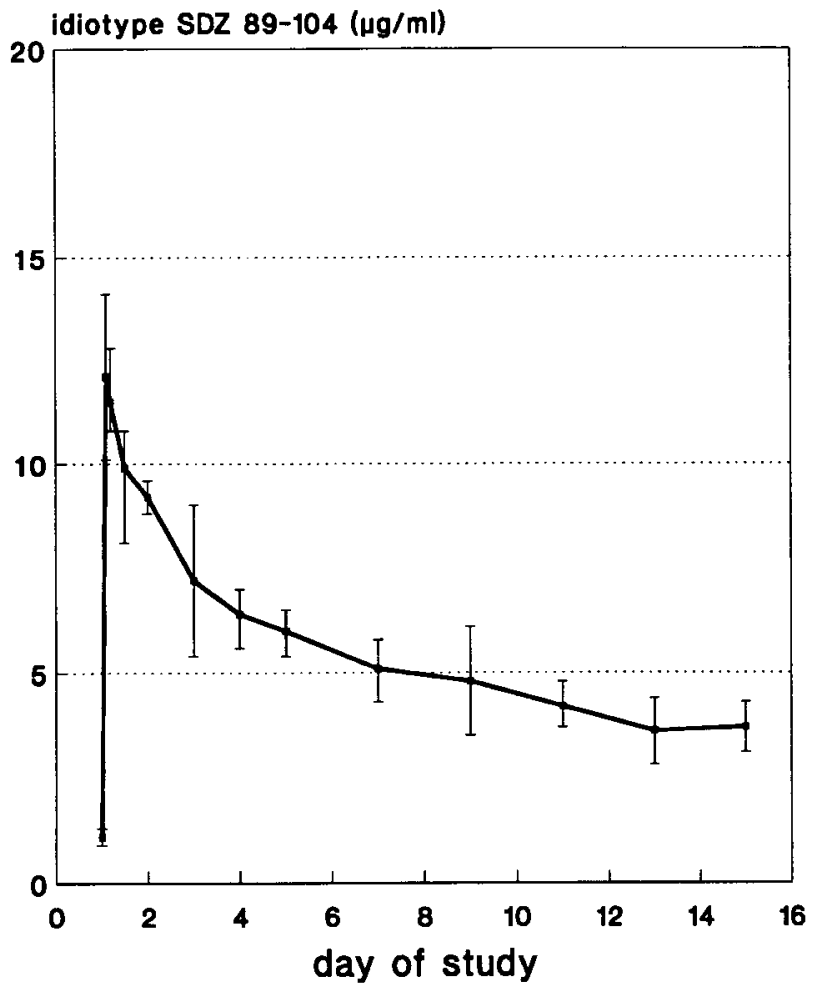

Neither clinical nor laboratory evidence of any acute or chronic toxicity of either antibody was observed. Vital signs and cardiac, pulmonary, liver, and kidney function were not altered by the treatment (data not shown). No circulating immune complexes or evidence for complement activation were detectable. Hematologic reconstitution occurred in patients treated with antibodies within the same time range as reported in the literature and observed in historic controls at our institution.

\section{Discussion}

This study showed that human monoclonal neutralizing antibodies for CMV can be safely administered to BMT recipients and that high serum levels of antibodies are achieved by biweekly administration over a 3-month period after transplantation. Moreover, these high serum levels were closely accompanied by increased neutralizing activity against CMV in patients treated with SDZ 89-109.

The elimination half-lives of human monoclonal antibodies were $\sim 6$ days. Thus the serum half-lives of human monoclonal antibodies are considerably longer than those reported after administration of murine monoclonal antibodies, where half-lives of $\sim 15 \mathrm{~h}$ after a single infusion were observed [4]. In investigations using mouse-human chimeric antibodies, half-lives were comparable to those of the two antibodies used

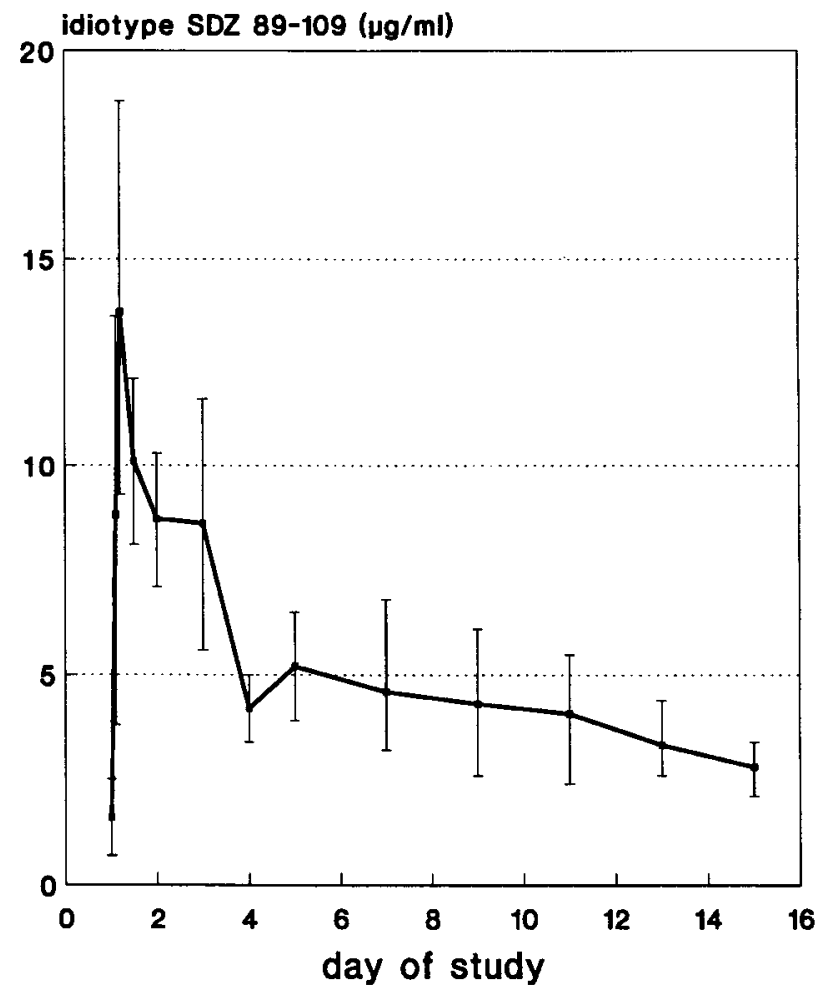

Figure 1. Idiotype levels (mean \pm SE) of monoclonal antibodies SDZ 89-104 or SDZ 89-109 in serum before and within 14 days of first infusion of $0.5 \mathrm{mg} / \mathrm{kg}$ of the antibodies in bone marrow transplant patients. 
in our study [11]. Although human IgG has been reported as being eliminated much more slowly than SDZ 89-104 and 89109 with a $\beta$ half-life of 20 days, the half-lives of CMV-specific IgG measured after treatment of BMT recipients with antiCMV hyperimmunoglobulin were similar to those observed with SDZ 89-109 and 89-104 [12, 13].

Two mechanisms might contribute to the accelerated clearance of both the CMV-specific monoclonal antibodies and CMV-specific IgG in BMT patients: First, such patients are in a highly catabolic state during the posttransplant period and accelerated elimination might therefore merely reffect enhanced protein turnover [14]. Second, the presence of viral antigens due to persistent infection with CMV might lead to specific binding of antibodies and thereby to an accelerated elimination. Nevertheless, as half-lives did not differ in clinically asymptomatic seropositive and seronegative individuals, it seems unlikely that latent infection with CMV would greatly influence the pharmacokinetics of the antibodies.

We conclude that it is feasible to maintain a high level of neutralizing antibodies against CMV in patients at risk for CMV disease by administering CMV neutralizing human monoclonal antibodies every second week. The efficacy of such a regimen for the prophylaxis of CMV disease will be tested in subsequent phase II trials.

\section{Acknowledgment}

We thank I. Bandtlow and B. Kropf for excellent technical assistance, C. Zommernig for secretarial help, and K. M. Sullivan, Seattle, for critical reading of the manuscript.

\section{References}

1. Reed EC, Bowden RA, Dandliker DS, Lilleby KE, Meyers JD. Treatment of cytomegalovirus pneumonia with ganciclovir and cytomega- lovirus immunoglobulin in patients with bone marrow transplants. Ann Intern Med 1988;109:783-8.

2. Sullivan KM. Immunoglobulin therapy in bone marrow transplantation. Am J Med 1987;83:34-45.

3. Schmitz $\mathrm{H}$, Essuman S. Comparison of the neutralizing and ELISA antibody titers to human cytomegalovirus in human sera and in gamma globulin preparations. J Med Virol 1986;20:177-82.

4. Khazaeli M, Saleh M, Wheeler R, et al. Phase I trial of multiple large doses of murine monoclonal antibody CO17-1A. II. Pharmacokinetics and immune response. J Natl Cancer Inst 1988;80:937-42.

5. Dillman RO, Shawler DL, Dillman JB, Royston I. Therapy of chronic lymphocytic leukemia and cutaneous $\mathrm{T}$ cell lymphoma with T101 monoclonal antibody. J Clin Oncol 1984;3:881-91.

6. Lubeck MD, Steplewski Z, Baglia F, Klein MH, Dorrington KJ, Koprowski $\mathbf{H}$. The interaction of murine IgG subclass proteins with human Fc receptor. J Immunol 1985;135:1299-304.

7. Ehrlich PH, Moustafa ZA, Justice JC, Harfeldt KE, Östberg L. Further characterization of the fate of human monoclonal antibodies in rhesus monkeys. Hybridoma 1988;7:385-95.

8. Utz U, Britt W, Vugler L, Mach M. Identification of a neutralizing epitope on the glycoprotein gp58 of human cytomegalovirus. J Virol 1989;63:1995-2001.

9. Borysiewicz LK, Morris KS, Page JD, Sissons JGP. Human cytomegalovirus specific cytotoxic T cells. Requirements for in vitro generation and specificity. Eur J Immunol 1983;13:804-9.

10. Andreoni M, Faircloth M, Vugler L, Britt W. A rapid microneutralisation assay for the measurement of neutralizing antibody reactivity with human cytomegalovirus. J Virol Methods 1989;23:157-68.

11. LoBuglio A, Wheeler R, Trang J, et al. Mouse human chimeric monoclonal antibody in man: kinetics and immune response. Proc Natl Acad Sci USA 1989;86:4220-4.

12. Morell A, Terry W, Waldmann TA. Metabolic properties of IgG subclasses in man. J Clin Ivest 1970;49:673-81.

13. Hagenbeek A, Brummelhius GJ, Donkers A, et al, Rapid clearance of cytomegalovirus-specific IgG after repeated intravenous infusions of human immunoglobulin into bone marrow transplant recipients. J Infect Dis 1987;155:897-902.

14. Cheney CL, Abson KG, Aker SN, et al. Body composition changes in marrow transplant recipients receiving total parenteral nutrition. Cancer 1987;59:1515-9. 